\title{
DIALOG MENURUT PANDANGAN GEREJA SEBAGAI JALAN MENYUBURKAN PLURALISME
}

\author{
Oleh: Wilfridus F. Beo Dey
}

\begin{abstract}
Abstrak:
Artikel ini bertujuan untuk menemukan pandangan Gereja Katolik tentang dialog sebagai jalan untuk menghidupkan pluralisme demi mewujudkan persatuan Indonesia dan sekaligus bertujuan untuk menemukan manfaat dialog bagi tumbuh-kembang pluralisme. Gereja Katolik sebagai sebuah institusi sosio-religius berperan dalam mempersatukan Indonesia. Gereja Katolik menjadi sebuah entitas yang mesti tetap dipikirkan sebagai salah satu penopang kontinuitas keindonesiaan. Penelitian ini menggunakan metode kepustakaan; penulis membaca literatur mengenai dialog dalam pandangan Gereja Katolik sembari mendalami bacaan-bacaan mengenai pluralisme. Hasil penelitian menunjukkan bahwa semangat, sikap dan nilai dialog merupakan salah satu jalan untuk menyuburkan pluralisme. Hasil lain yang diperoleh bahwa gereja Katolik mempunyai pandangan yang amat positip tentang dialog dan dialog dinilai sebagai satu pandangan Gereja yang amat bermanfaat bagi tumbuh dan perkembangnya pluralisme demi mewujudkan persatuan Indonesia.
\end{abstract}

Kata-kata Kunci: Dialog, Pluralisme, Gereja Katolik, Persatuan Indonesia.

\section{Pengantar:}

I

su tentang pluralisme semakin dirasa penting untuk dikedepankan karena realitas konflik dan pertentangan di tingkat internasional semakin marak terjadi. Konflik ini dipicu oleh pelbagai macam keragamaan dan perbedaan yakni perbedaan agama, suku, ras, adat istiadat, pilihan politik dan kepentingan yang amat sulit untuk dijembatani. Perang antar negara, perang antar suku di dalam negara, perang antar agama yang ada di sebuah negara, perebutan wilayah negara, perang karena perbedaan pilihan politik telah memakan banyak korban jiwa maupun harta benda. Perang-perang ini seolah-olah mengafirmasi adagium tua yang menandaskan bahwa "jika ingin berdamai maka, bersiaplah untuk perang" (Si vis Pacem, para bellum). ${ }^{1}$ Perang menjadi solusi untuk mengakhiri konflik karena perbedaanperbedaan dan keragamaan dalam kehidupan sosial.

Di level nasional konflik-konflik karena keragamaan juga terjadi amat jamak dalam kehidupan bangsa Indonesia. Keragamaan yang nyata dalam perbedaan agama, suku, ras, budaya dan pilihan-pilihan politik menjadi pemantik terjadinya konflik sosial, padahal sudah ditegaskan sejak bangsa Indonesia didirikan bahwa Negara Kesatuan Republik Indonesia berdiri atas dasar Bhineka Tunggal Ika. Keragamaan yang timbul karena perbedaanperbedaan tersebut adalah fakta terberi yang tidak bisa dianulir selain menerima dengan penuh respek perbedaan-perbedaan itu sebagai kekayaan yang menyatu dalam ke-Indonesiaan.

\footnotetext{
${ }^{1}$ Ungkapan ini dicetuskan oleh Sejarawan Romawi Titus Livius (59 Sm-17 M) sebagai sebuah adagium klasik dan konservatif tentang sebuah metode resolusi konflik yang rasional, sah dan tetap berlaku; bahwa kekerasan hanya bisa dilumpuhkan dengan kekerasan. Sifat konservatif cara pandang itu setidaknya kemudian dapat dilacak dalam pelbagai konvensi yang mengatur hukum perang internasional tentang bellum iustum atau just war. Bdk. Robert B. Baowolo, Menggugat Tanggung Jawab Agama-Agama Abrahamik bagi Perdamaian Dunia (Yogyakarta: Kanisius, 2010), hlm. 10.
} 
Pluralisme menjadi sebuah usaha, semangat sekaligus tuntutan untuk hidup dalam bangsa besar yang bernama Indonesia. Kemajemukan telah menjadi ciri khas bangsa ini. Menolak adanya kemajukan sama dengan menolak untuk berada dan tinggal di Indonesia. Sebagai sebuah usaha, pluralisme adalah sebuah kata yang aktif sebab menuntut perjuangan dari seluruh komponen bangsa dengan usaha yang terus menerus untuk dihidupkan di bumi Indonesia. Sebagai sebuah semangat, pluralisme adalah roh yang menjadikan keragamaan budaya, agama, etnis, suku dan ras terjaga dalam bingkai kesatuan sebuah bangsa. Di sisi lain, pluralisme juga merupakan tuntutan bagi seluruh komponen bangsa. Artinya siapapun yang menjadi warga negara Indonesia, menghidupkan pluralisme adalah tuntutan atau kewajiban dan bukanlah sebuah pilihan. Pertanyaan lanjutannya adalah bagaimana mewujudkan pluralisme di Indonesia?

Penulis menawarkan gagasan dialog sebagai sarana menghidupkan pluralisme. Dialog yang digagaskan ini bersumber dari ajaran Gereja Katolik. Ada pelbagai macam pemahaman tentang dialog yang akan digunakan sebagai pendasaran untuk mewujudkan pluralisme. Dalam konteks ini pluralisme adalah semangat untuk mewujudkan persatuan Indonesia dan dialog dengan segala macam pemahamannya dipakai sebagai sarana untuk menghidupinya. Maka pandangan-pandangan Gereja tentang dialog dan kajian-kajian tentang pluralisme akan dijadikan sebagai rujukan untuk menemukan signifikansi dialog dalam mewujudkan pluralisme.

\section{Memahami Dialog}

Pemahaman tentang dialog tidak bisa lepas dari sebuah pernyataan dalam Konsili Vatikan II yakni Nostra Aetate yang berbicara tentang hubungan antara Gereja dengan agama-agama non-kristen:

Gereja katolik tidak menolak apapun yang benar dan suci di dalam agama-agama ini. Dengan sikap hormat yang tulus, Gereja merenungkan cara-cara bertindak dan hidup, kaidah-kaidah serta ajaranajaran, yang memang dalam banyak hal berbeda dari apa yang diajari dan diyakini sendiri, toh tidak jarang memantulkan sinar kebenaran, yang menerangi semua orang...maka gereja mendorong para putranya, supaya dengan bijaksana dan penuh kasih, melalui dialog dan kerjasama dengan para penganut agama-agama lain, sambil memberi kesaksian tentang iman serta peri hidup kristiani, mengakui, memelihara dan mengembangkan harta kekayaan rohani dan moral serta nilainilai sosial budaya, yang terdapat pada mereka. ${ }^{2}$

Pernyataan ini menunjukkan sikap Gereja yang amat positip terhadap agama-agama non-Kristen. Gereja berkeyakinan dan mengajarkan kepada umatnya tentang kebenarankebenaran yang ada pada agama lain. Agama-agama lain mempunyai kebenaran dan sekaligus sebagai tanda penyaluran rahmat Allah. Pernyataan ini melahirkan babak baru sejarah pengakuan realitas pluralisme religious dan ingin bersikap terbuka terhadap kebenaran yang ada pada agama-agama non-Kristen. Karena itu orang-orang Kristen diajarkan untuk membangun dialog dan kerjasama dengan agama-agama lain. Melalui dialog antar umat beragama diharapkan dapat mewujudkan hubungan yang harmonis.

Pada bagian lain dari dokumen Konsili Vatikan II ditegaskan soal keterlibatan orang lain dalam dialog. Konsili Vatikan II menyatakan: “... kita tidak dapat menyeruhkan nama Allah Bapa Semua orang, bila terhadap orang-orang tertentu, yang diciptakan menurut citra kesamaan Allah, kita tidak mau bersikap sebagai saudara. Hubungan manusia dengan Allah dan sesama saudaranya begitu erat, sehingga siapa yang tidak mencintai, ia tidak mencintai

\footnotetext{
${ }^{2}$ Konsili Vatikan II, Nostra Aetate, NA. Art. 2, penerj. Hardawirayana, (Jakarta: Obor, 1993), hlm. 311.
} 
Allah". ${ }^{3}$ Artinya, "Setiap manusia memiliki satu asal usul dan satu tujuan yakni, Allah. Selain itu dialog punya dasar Kristologis melalui peristiwa inkarnasi, dimana Kristus sendiri hadir sebagai pendamai antara Allah dan manusia. Kristus memulihkan hubungan antara Allah dan manusia akibat dosa. Melalui Kristus dan dalam peristiwa inkarnasi, dialog sungguh-sungguh nyata dan menjadi model bagi dialog antar umat manusia. Setelah peristiwa inkarnasi Kristus, dialog dilanjutkan oleh Roh Kudus. Roh Kudus menjadi pemersatu bukan saja antar orang per orang melainkan menjadi pemersatu masyarakat, bangsa, budaya dan agama-agama. Kemudian melalui Gereja yang merupakan kumpulan orang-orang yang dibabtis menjadi tempat yang tampan untuk berdialog. Gereja menjadi tempat persekutuan seluruh umat beriman dengan latar belakang suku, budaya, bangsa yang beranekaragam. Gereja menjadi tanda nyata kehadiran Kristus di dunia. Karena itu pertemuan, interaksi dengan agama-agama lain yang hidup di dunia merupakan hal yang tidak bisa dihindari sehingga dalam konteks tersebut Gereja mesti membangun sikap dialogis dengan umat beragama lain. Selanjutnya, dasar lebih realistik lagi soal keharusan dialog yang digagaskan Gereja adalah faktor antropologis dan moral. Dasar antropologis dan moral merujuk pada anugerah akal budi yang dimiliki setiap manusia yang bertanggung jawab entah secara pribadi dan secara bersama-sama untuk mencari kebenaran termasuk kebenaran yang ada dalam agama-agama. Ini berarti setiap agama apapun yang dianut oleh manusia memiliki kebenaran yang pasti diperjuangkan secara moral. Ikhtiar untuk menemukan dan mempertahankan kebenaran agama masing-masing tetap dijalankan dalam semangat dialog agar tidak terjadi klaim kebenaran agama yang absolut dan meniadakan kebenaran moral yang terkandung pada agama lain." ${ }^{4}$

Term dialog memiliki beberapa arti. Ada banyak dokumen Gereja yang berbicara tentang dialog, namun di sini disebutkan hanya dua dokumen sebagai contoh yakni dialog and mission (1984) dan Dialog Proclamation (1981) yang secara tegas mencetuskan pengertian dialog. Dialog Proclamation (DP. 9) membedakan tiga macam arti dialog. Arti pertama dalam tingkatan manusiawi sehari-hari, dialog merupakan komunikasi timbal balik. Tujuan komunikasi jenis ini sekedar saling tukar menukar informasi, atau untuk meraih kesepakatan, atau menjalin persatuan. Arti kedua, lebih berkaitan dengan tugas evangelisasi yang harus dijalankan dalam semangat dialogal. Dialog ini berkaitan dengan sikap hormat, penuh persahabatan, ramah, terbuka dan suka mendengarkan orang lain. Arti ketiga, berhubungan dengan dialog dengan agama-agama lain. ${ }^{5}$ Dialog dalam 3 pengertian ini akan menjadi fokus dalam artikel ini.

Dialog dalam tingkatan manusiawi sehari-hari menjadi dasar untuk dialog evangelis. Gereja menyadari bahwa manusia adalah makhluk sosial yang membutuhkan sesamanya. Tuntutan sebagai makhluk sosial menempatkan komunikasi dalam bentuk dialog sebagai hal yang penting. Dialog yang sama dipakai sebagai sarana evangelisasi dan evangelisasi akhirnya dilaksanakan juga melalui dialog yang intensif dengan komunitas-komunitas atau pribadi-pribadi tertentu demi mencapai kematangan iman.

Berdialog atau bercakap-cakap merupakan cara yang dipakai untuk menyelami problem sosial kebangsaan. Seri dokumen Gereja, Dialog dan Misi (DM) mengartikan dialog sebagai berikut:

\footnotetext{
${ }^{3}$ NA. Art. 5.

${ }^{4}$ Amrosius Wurittimur, Gereja Berdialog Menurut Ajaran Magisterium (Jakarta: Obor, 2018), hlm. 6365

5 Armada Riyanto, Dialog Agama Dalam Pandangan Gereja Katolik (Yogyakarta: Kanisius, 2006), hlm. 102.
} 
dialog dapat dimengerti dengan bermacam-macam cara. Pertama-tama, pada tingkat manusiawi semata-mata, dialog berarti komunikasi timbal balik, yang terarah kepada suatu tujuan bersama, atau pada tingkat lebih dalam, terarah ke persatuan antar pribadi. Kedua, dialog dapat dianggap sebagai suatu sikap hormat dan persahabatan, yang meresapi atau hendaknya meresapi semua kegiatan yang membentuk perutusan evangelisasi Gereja (DM 9). ${ }^{6}$

Kutipan di atas patut dijadikan landasan dalam berdialog sehingga tidak terjerumus ke dalam pemaksaan kehendak dari satu pihak ke pihak lain. Dialog dalam pengertian pertama lebih terarah kepada dialog sehari-hari, sebagai komunikasi timbal balik, sekedar saling tukar informasi atau untuk mencapai kesepakatan untuk menjalin persatuan. Pengertian kedua lebih berkaitan dengan evangelisasi. Di sini dialog dipahami sebagai sikap hormat, penuh persahabatan, ramah, terbuka, suka mendengarkan sebagai wujud pengkonkritan nilai-nilai Injil. Dialog akan bermakna apabila kedua belah pihak saling terbuka untuk mendengarkan dan saling menghormati dalam memberi masukan. Dalam dialog, posisi orang-orang yang terlibat berada pada level yang sama, sederajad. Sama-sama menjadi subyek yang otonom karena itu penghargaan terhadap pikiran dan perasaan sangat diperhatikan.

Maka dalam konteks pluralitas agama, dialog tidak hanya berarti diskusi, melainkan berupa relasi yang bersifat membangun antara pribadi-pribadi dan komunitas-komunitas agama yang berbeda, yang membawa mereka kepada relasi saling memahami karena ketaatan kepada kebenaran dan rasa hormat kepada kebebasan. Dialog pada tahap ini menyangkut kesaksian dan eksplorasi keyakinan agama masing-masing. Dan dalam konteks inisiatif Gereja untuk menjangkau umat beragama lain, dialog dipahami sebagai sikap hormat dan persahabatan yang menyerap semua misi evangelisasi di dunia. ${ }^{7}$ Dialog yang dibangun tidak lagi sekedar menunjukkan kelincahan argumentasi yang masuk akal melainkan lebih dari itu harus menjadi sikap hidup yang menempatkan sikap menghargai secara total peebedaan-perbedaan tanpa harus saling mempertajam perbedaan-perbedaan tersebut secara rasional.

Menurut FABC (Federation Asian Bishop Counsil), dialog yang dikembangkan dalam konteks Asia adalah dialog kehidupan. Berbicara tentang dialog berarti berbicara tentang pelaku dialog. Pelaku dialog itu adalah manusia. Berkaitan dengan dialog di Asia, yang menjadi pelaku dialog adalah orang-orang Asia sendiri. Pelaku utama misi baru dalam dialog itu adalah jemaat setempat yang meliputi, paroki, keluarga, lembaga-lembaga seperti sekolah, pusat-pusat reksa kesehatan, bahkan badan-badan komersial tempat orang mengalami cita rasa keanggotaan yang kuat, termasuk unsur-unsur konstitutif jemaat setempat. ${ }^{8}$ Dialog kehidupan mengambil tempat dalam situasi konkrit umat dan terungkap dalam praksis hidup yang tidak mengenal perbedaan ras atau golongan, status atau jabatan dan aliran keagamaan. Setiap pemeluk agama berjuang untuk membangun hidup bersama sebagai tetangga secara damai dan saling membantu dalam mengatasi pelbagai persoalan. Segala kesusahan dan kesulitan masyarakat adalah bagian dari kehidupan Gereja.

Meski pengertian dialog di atas tertuju kepada dialog antar-iman tetapi spirit universal dari dialog ada di dalam pengertian tersebut yakni prinsip saling mendengar, menghargai perbedaan dan membongkar prasangka serta manipulasi dalam kehidupan bersama. Dialog

${ }^{6}$ Seri Dokumen Gereja, Dialog dan Pewartaan, No. 9, penerj. J. Hadiwikarta, (Jakarta: DOKPEN KWI, 1984), hlm. 3. Teks bahasa Inggris berbunyi: “Dialogue and Proclamation” (Reflection and Orientation on Interreligious Dialogue and The Proclamation of the Gospel of Jesus Christ). Dokumen ini dikeluarkan secara bersama-sama oleh Kongregasi Suci untuk Evangelisasi Bangsa-Bangsa dan dewan kepausan untuk dialog antar Agama sebagai penegasan, bahwa dialog dan pewartaan saling berhubungan tetapi tidak persis sama.

${ }^{7}$ Amrosius Wurittimur, Op.Cit., hlm. 62-63.

${ }^{8}$ Seri Dokumen Gereja, Dokumen Sidang-Sidang Federasi Konferensi-Konferensi Para Uskup Asia 1970-1991, penerj. R. Hardawiryana, (Jakarta: DOKPEN KWI, 1995), hlm. 538. 
tidak bermaksud menyuburkan sikap permisif terhadap ketimpangan dalam hidup bersama tetapi menempatkan sikap kritis demi membongkar kecurigaan.

Gagasan tentang dialog ditegaskan dengan sebuah pernyataan KV II tentang Dignitatis Humanae, yang secara khusus berbicara tentang pentingnya kebebasan beragama. Dialog saja tidak cukup maka perlu ada sikap Gereja tentang penghormatan terhadap kebebasan beragama:

Maka terjadilah ketidakadilan terhadap pribadi manusia dan tata sosial yang ditetapkan oleh Allah baginya, bila ia tidak diperbolehkan mengamalkan agamanya secara bebas dalam masyarakat, padahal ketertiban umum yang adil tetap dihormatinya. Kecuali itu tindakan-tindakan keagamaaan, untuk sebagai pribadi maupun di muka umum mengarahkan diri kepada Allah berdasarkan keputusan pribadi, pada hakikatnya mengatasi tata duniawi yang fana. Maka dari itu pemerintah, yang bertujuan mengusahakan kesejahteraan umum di dunia ini memang wajib mengakui kehidupan beragama para warga negara dan mendukungnya. Tetapi harus diakui melampaui batas wewenangnya, bila memberanikan diri mengatur dan merintangi kegiatankegiatan religius. ${ }^{9}$

Kutipan di atas memperlihatkan beberapa ajaran pokok terkait kebebasan yang merupakan syarat terciptanya dialog antaragama yakni:

a. Kebebasan beragama berarti bahwa tidak dapat dipaksa untuk melawan suara hatinya, entah dari kelompok atau dari pribadi tertentu.

b. Kebebasan beragama didasarkan pada martabat pribadi manusia. Manusia sesuai kodratnya memiliki hak untuk mencari kebenaran moral yang terkait dengan agama.

c. Cara orang mencari kebenaran agama harus sesuai dengan martabat pribadi dan kodrat sosialnya, misalnya melalui penyelidikan, pengajaran, komunikasi dan dialog.

d. Kaum beragama memiliki hak sebagai jemaat selama tidak menggangu kepentingan umum.

e. Agama memiliki aspek sosial-politis maka keterlibatan agama di dalam masyarakat harus dijamin oleh negara.

f. Aspek misioner juga terwujud di dalamnya, yakni jemaat beragama dijamin kebebasan untuk mengajarkan iman dan memberi kesaksian di muka umum. ${ }^{10}$

Beberapa penjelasan terhadap dekrit tentang kebebasan beragama (DH) ini memperlihatkan secara sempurna bahwa dialog hanya mungkin terjadi dalam suasana penuh dengan kebebasan. Kebebasan beragama adalah syarat supaya suasana dialog dilaksanakan dalam nuansa perhargaan yang tulus tanpa bermaksud untuk menggurui apalagi menganggap agama sendiri lebih superior ketimbang yang lain.

Terkait hal ini, Paus Fransiskus dan Imam besar Al-Azhar, Ahmed Al-Tayeb menandatangani sebuah dokumen tentang persaudaran dan insani demi perdamaian:

"Dalam nama Allah dan segala sesuatu yang dinyatakan sejauh ini; Al-Azhar al Sharif dan kaum muslim di Timur dan Barat, Bersama dengan Gereja Katolik dan umat Katolik di Timur dan di Barat, menyatakan menerima budaya dialog sebagai jalan; kerjasama timbal balik sebagai kode tingkah laku; saling pengertian sebagai metode dan standar. Kami yang percaya kepada Allah dan pada perjamuan terakhir dengannya dan pengadilannya, berdasarkan tanggung jawab religious dan moral kami, dan melalui dokumen ini, menyeruhkan kepada diri kami sendiri, kepada para pemimpin dunia serta para arsitek kebijakan internasional dan ekonomi dunia agar bekerja keras untuk menyebarkan budaya toleransi dan hidup bersama dalam damai; agar mengadakan intervensi pada kesempatan lebih awal untuk menghentikan penumpahan darah orang-orang yang tidak

\footnotetext{
${ }^{9}$ DH. Art. 3.

${ }^{10}$ Adrianus Sunarko, Teologi Kontekstual (Jakarta: Obor, 2018), hlm. 360-362.
} 
bersalah dan mengakhiri perang, konflik, kerusakan lingkungan, serta kemerosotan moral dan budaya yang dialami saat ini." 11

Kesepakatan ini merupakan produk terbaru hasil pergumulan dua pemimpin besar yang amat konsen pada keberlanjutan dialog antar-agama.

\section{Pluralisme di Indonesia}

Perjumpaan antara agama-agama yang hidup dan berkembang di Indonesia telah tercatat di dalam kanvas sejarah. Sebelum Hinduisme dan Budhisme masuk ke wilayah Nusantara, agama-agama suku yang berbentuk animisme, dinamisme telah menjadi warna dalam kehidupan Masyarakat Nusantara. Kehadiran Budhisme, Hinduisme dan bahkan Islam dan Kristen di kemudian hari bertumbuh dalam kultur nusantara yang memiliki karakter pluralis dan akomodatif. Corak ini membuat wajah Islam dan Kristen di Indonesia memiliki wajah yang toleran jika dibandingkan dengan pemeluk agama Islam dan Kristen di wilayah Timur Tengah. Kedua agama besar ini ini justru lebih mampu hidup dalam keragamaan (pluralis) dan terbuka. ${ }^{12}$

Pluralisme Indonesia memiliki akar historis sebab Indonesia adalah termasuk daerah penting dalam perdagangan dunia karena hasil rempah-rempahnya. Agama asli masyarakat Indonesia dapat disimpulkan sebagai "agama suku" (van den End, 13). Setiap suku memiliki agama masing-masing. Tetapi coraknya sama yaitu terikat pada suku tersebut, dan tak bisa dipisahkan dari adat/budaya suku tersebut, dewa hanya untuk suku tersebut, dan memiliki mitos tersendiri. Hidup dalam dunia spiritisme. Tata masyarakat yang kolektivisme. Kedatangan agama Hindu, Buddha dan Islam di Indonesia (Maluku) yang dikenal dengan rempah-rempah. Para pedagang membawanya ke Jawa dan Sumatera dan diekspor ke India, sehingga terjadi mata rantai perdagangan yang luas dan besar pada waktu itu. Muncul kerajaan besar seperti Sriwijaya, Majapahit, Pajajaran dan juga muncul kerajaan-kerajaan kecil. Agama Hindu dan Buddha sejak abad ke-7 datang ke Indonesia melalui perdagangan. Di Sumatera berkembang agama Buddha dan di Jawa berkembang agama Hindu. Agama Hindu tidak mengubah agama suku, malah terjadi saling memperkaya agama setempat, sehingga Hindu yang ada di Indonesia tidak sama dengan Hindu yang ada di India. Agama Islam juga datang lewat jalur perdagangan pada abad ke 13. Ciri penyebaran Islam yakni: (1) Perdagangan dan penyiaran Islam lewat kota pelabuhan. (2) Pernikahan dengan puteri bangsawan setempat (van den End, 20). (3) Raja-raja yang menerima Islam meneruskan pengislaman ke pedalaman. (4) Daerah yang telah Islam adalah Aceh, Malaya, Sumatera, Jawa dan Maluku. Jadi Islam sudah menjadi agama di tempat strategis wilayah Indonesia bagian Barat. ${ }^{13}$ Catatan historis ini memperlihatkan bahwa Indonesia bersifat plural jauh sebelum Indonesia merdeka. Kehadiran agama-agama yang berasal dari luar Nusantara tidak mengubah wajah Nusantara melainkan memperkaya ke-Indonesia-an dan menjadikan Indonesia (Nusantara) plural.

Pluralisme diartikan sebagai kerangka interaksi tempat setiap kelompok menampilkan rasa hormat dan toleran satu sama lain, berinteraksi tanpa konflik atau asimilasi. Pluralisme tidak sekedar menyatakan bahwa masyarakat kita majemuk, terdiri dari berbagai agama dan suku karena justru akan mengesankan adanya fragmentasi. Pluralisme harus dipahami

11 Dokumen tentang persaudaraan Insani demi perdamaian dunia dan hidup Bersama oleh Paus Fransiskus dan Imam besar Al-azhar, Ahmed Al-Tayeb; menandatangani dokumen ini sebagai hasil dari Konverensi Global tentang topik ini di Abu Dhabi, Februari 2019, diterjemahkan oleh Martin Harun.

12 Tim Impulse, Mencungkil Sumbatan Toleransi (Yogyakarta: Kanisius, 2010), hlm. 200-201.

${ }^{13}$ Stipar, Sejarah Gereja Indonesia (ms) (Ende: Stipar, 2010), hlm. 67-68. 
sebagai pertalian sejati kebinekaan dalam ikatan-ikatan keadaban. Lebih daripada itu, pluralisme adalah suatu keharusan bagi keselamatan umat manusia, antara lain melalui mekanisme pengawasan dan pengimbangan yang dihasilkan. Kautzar Azhari Noer mengatakan, pluralisme adalah sikap yang mengakui sekaligus menghargai, menghormati, memelihara dan mengembangkan atau memperkaya keadaan yang bersifat plural, jamak atau banyak. Ini berarti pengertian pluralisme merujuk pada fakta secara historis dan sosiologis masyarakat, bukan untuk saling menguasai dan menundukan. Tetapi justru berangkat dari pemahaman bahwa sesungguhnya setiap agama itu baik dan benar. Karenanya setiap agama harus dihargai, bukan karena penghargaan itu penting, tetapi justru karena kebaikan dan kebenaran itu jauh lebih penting. ${ }^{14}$ Fakta historis dan sosiologis tentang pluralisme yang ada di dalam bangsa Indonesia bukanlah sebuah konsep luar yang dipaksakan untuk diterapkan ke dalam konteks kejamakan masyarakat Indonesia melainkan produk asli bangsa Indonesia yang banyak kali luput dari perhatian karena ditutup oleh paham-paham radikalisme yang anti-toleransi.

Kebebasan adalah hak setiap orang: setiap individu menikmati kebebasan berkeyakinan, berpikir, berekspresi dan bertindak. Pluralisme dan keragaman agama, warna kulit, jenis kelamin, ras dan bahasa dikehendaki oleh Allah dalam hikmatnya, yang dengannya ia menciptakan manusia. Dari sumber hikmat Ilahi inilah berasal hak kebebebasan berkeyakinan dan kebebasan untuk berbeda. Oleh karena itu, kenyataan bahwa orang dipaksakan untuk mengikuti agama atau budaya tertentu harus ditolak, seperti juga memaksakan suatu cara hidup budaya yang tidak diterima oleh orang lain.

\section{Dialog Sebagai Jalan Mewujudkan Pluralisme}

Salah satu adagium filosofis yang cukup penting dikutip yakni: "kalo yang ada hanya persamaan maka dialog tidak perlu dan kalau yang ada hanya perbedaan maka dialog tidak mungkin". Adagium ini hanya sekedar mengingatkan bahwa dialog untuk menyuburkan pluralisme hanya bisa terjadi jika masing-masing pihak yang terlibat di dalam dialog menyadari tentang persamaan-persamaan dan perbedaan-perbedaan yang ada di dalam masing-masing kelompok yang menjadi fakta terberi. Kondisi ini akan membuka kemungkinan terjadinya usaha-usaha dialog antar kelompok-kelompok sehingga tercipta pemahaman tentang pluralisme.

Paus Fransiskus dalam himbauan Apostolik Evangelii Gaudium memperlihatkan urgensi dialog sebagai bagian dari tugas umat Kristiani dan seluruh komunitas religius. ${ }^{15}$ Dialog mula-mula bukanlah suatu pembicaraan melainkan sebuah sikap terbuka kepada orang-orang yang mengalami krisis-krisis besar di dalam kehidupan yang dilandasi oleh kasih. Maka penekanan yang diberikan Paus Fransiskus lebih tertuju kepada hal-hal realistis menyangkut keprihatinan terhadap kemanusiaan universal. Tema-tema aktual terkait kepentingan bersama seluruh umat manusia bisa menjadi jembatan sekaligus sebagai tema dialog. Beberapa keprihatinan universal seperti problem kerusakaan alam, penodaan terhadap martabat manusia, perang antar negara, kelaparan dapat menjadi tema-tema paling realistik dalam bingkai dialog kehidupan. Di tengah-tengah penderitaan dan keprihatinan, manusia bisa saling memunculkan simpati yang mendalam tanpa perlu mepersoalkan perbedaan teologis dan klaim kebenaran agama. Di titik ini pluralisme pelan-pelan dibangun tanpa harus dikomandoi oleh suatu konsep dialog yang saintifik dan ketat. Tanpa perlu metode berpikir yang serius yang hanya berujung pada berdebatan tanpa akhir.

\footnotetext{
14 Tim Impulse, Op.Cit., hlm. 202.

15 Konsili Vatikan II, Evangelii Gaudium, EG. Art. 250
} 
Benang merah yang dapat ditarik dari pluralisme adalah suatu kondisi yang memungkinkan semua anggota masyarakat yang berbeda agama, suku, ras dan golongan serta pilihan politik memiliki pemahaman bersama tentang pentingnya menghargai perbedaan. Pluralisme menjadi suatu prinsip bahwa ras, agama dan pandangan politik yang berbeda dapat hidup secara damai dalam masyarakat yang sama. Selain itu, pluralisme didefinisikan sebagai sebuah doktrin metafisis yang menyatakan bahwa semua wujud pada akhirnya dapat dilebur dalam suatu keanekaragaman perbedaan dan wujud atau elemen tersebut dapat berdiri sendiri. ${ }^{16}$

Dalam konteks Katolik dasar teologis tentang ide dialog tidak dapat dibantah. Ada beberapa dokumen yang berbicara tentang dialog. Paling kurang ada tiga gagasan penting terkait dialog yakni dialog kehidupan, dialog teologis, dialog etis. Semuanya memiliki peluang untuk dikembangkan di Indonesia. Dialog pada tataran teologis merupakan tawaran yang hanya menyasar kelompok elit intelektual dan ini adalah pekerjaan besar yang membutuhkan waktu yang panjang sebab selalu terkait dengan kebenaran absolut masingmasing agama yang sulit untuk didamaikan. Namun amat menggembirakan saat bicara tentang dialog etis sebagai sesuatu yang lebih realistis dalam membangun kerukunan antar umat beragama. Isu-isu etis terkait kemanusiaan dan lingkungan hidup bisa menjadi salah satu jembatan sekaligus bentuk dialog yang paling mungkin untuk dilaksanakan.

\section{Catatan Penutup}

Dialog menjadi jalan menyuburkan pluralisme. Konsep dialog telah menjadi satu kekayaan dalam Gereja Katolik sejak Konsili Vatikan II. Kekayaan Gereja ini bisa menjadi sumbangan bagi harmonisasi agama-agama di dunia dan sekaligus dapat menjadi model dan spirit dalam membangun pluralisme di Indonesia. Melalui beberapa dokumen, gereja memberikan sumbangan besar bagi kemajemukan bangsa Indonesia. Kesediaan Gereja untuk mengubah cara pandang terhadap agama-agama non-Kristen menjadi angin segar bagi tumbuh-kembang pluralisme. Pluralisme menjadi sebuah tuntutan yang tidak bisa ditolak dalam sebuah bangsa yang majemuk. Salah satu sumbangan Gereja dalam menyuburkan pluralisme adalah dialog.

Dialog diatur dengan baik oleh Gereja sebagai bentuk pertanggungjawaban iman seluruh umat Kristiani dan segenap komunitas religius. Dialog adalah tugas misioner yang diberikan atau diajarkan gereja kepada seluruh umat Kristiani apalagi di tempat-tempat yang diwarnai oleh kemajemukan seperti di Indonesia. Sikap ini adalah tuntutan dalam negara bangsa (nation-state) yang majemuk seperti di Indonesia. Artinya siapapun yang hendak hidup di Indonesia wajib menghidupkan pluralisme dan salah satu jalan menyuburkan pluralisme adalah melalui dialog dengan segala bentuk dan model yang bisa dipraktekan dalam kehidupan sehari-hari sambil tetap menghargai kebebasan beragama masing-masing pemeluknya.

${ }^{16}$ James Hasting (ed.), Encyclopedia of Religion and Ethics (New York: Charles Scribnes Sons Ltd, t.th) vol. x. hlm. 66 . 


\section{Daftar Kepustakaan}

Konsili Vatikan II, Nostra Aetate. Art. 2 dan 3, penerj. Hardawirayana. Jakarta: Obor, 1993. , Evangeli Gaudium. Art. 250, penerj. Hardawirayana. Jakarta: Obor, 1993. , Dignitatis Humane. Art. 3, penerj. Hardawirayana. Jakarta: Obor, 1993.

Baowolo, Robert B. Menggugat Tanggung Jawab Agama-Agama Abrahamik bagi Perdamaian Dunia. Yogyakarta: Kanisius, 2010.

Hasting, James (ed.), Encyclopedia of Religion and Ethics. New York: Charles Scribnes Sons Ltd, t.th) vol. $\mathrm{x}$.

Paus Fransiskus dan Ahmed Al-Tayeb, Dokumen tentang persaudaraan Insani demi perdamaian dunia dan hidup Bersama, terj. Martin Harun. Abu Dhabi, Februari 2019.

Riyanto, Armada. Dialog Agama Dalam Pandangan Gereja Katolik. Yogyakarta: Kanisius, 2016.

Sunarko, Adrianus, Teologi Kontekstual. Jakarta: Obor, 2018.

Seri Dokumen Gereja, Dokumen Sidang-Sidang Federasi Konferensi-Konferensi Para Uskup Asia 1970-1991, penerj. R. Hardawiryana, Jakarta: DOKPEN KWI, 1995.

Stipar, Sejarah Gereja Indonesia (ms). Ende: Stipar, 2010.

Tim Impulse, Mencungkil Sumbatan Toleransi. Yogyakarta: Kanisius, 2010.

Wurittimur, Amrosius. Gereja Berdialog Menurut Ajaran Magisterium. Jakarta: Obor, 2018 . 